\title{
Diet of Astyanax paranae (Characidae) in streams with different riparian land covers in the Passa-Cinco River basin, southeastern Brazil
}

\author{
Anderson Ferreira ${ }^{1}$, Pedro Gerhard ${ }^{2} \&$ José E. P. Cyrino $^{1}$
}

\author{
1. Universidade de São Paulo (USP), Escola Superior de Agricultura "Luiz de Queiroz" - ESALQ, Setor de Piscicultura, Av. Pádua Dias, 11, Bairro Agronomia, 13418-900, Piracicaba, SP, Brasil. \\ (andersaof@gmail.com) \\ EMBRAPA Amazônia Oriental, Travessa Dr. Enéas Pinheiro, s/nº, Caixa Postal 48, 66095-100, Belém, PA.
}

\begin{abstract}
An analysis of the diet of Astyanax paranae Eigenmann, 1914 in nine streams located in the Passa-Cinco River basin (upper Paraná River system) was performed to investigate the feeding habits of this species, check for possible spatial variations in diet and to investigate the influence of riparian vegetation in the composition of the diet. Stomach contents of 243 specimens were analyzed by the methods of relative frequency of occurrence and volume, and the diet was characterized by the alimentary index $\left(\mathrm{AI}_{\mathrm{i}}\right)$. The species showed insectivorous feeding habits, with a predominance of terrestrial and aquatic insects in the diet, varying by location. In most streams, resources of allochthonous origin were the most consumed. The participation of aquatic insects and terrestrial plants were high in most streams, while terrestrial insects and invertebrates were highest in streams with a greater presence of riparian forest. The two streams located draining pasture fields were the only places were $A$. paranae consumed algae and macrophyte fragments. These results were corroborated by the analysis of similarity (ANOSIM): the descriptor "percentage of riparian forest" was the highest environmental influence on the diet of $A$. paranae. The study shows that riparian forest percentage on the stream reach determines the species diet composition, but $A$. paranae is also able to gather enough food resources in a variety of severely degraded environments.
\end{abstract}

KEYWORDS. Feeding ecology, Characiformes, insectivorous fishes, habitat features.

\begin{abstract}
RESUMO. Dieta de Astyanax paranae (Characidae) em riachos com diferentes coberturas ripárias na bacia do rio Passa-Cinco, sudeste do Brasil. A análise da dieta de Astyanax paranae Eigenmann, 1914 em nove riachos localizados na bacia do rio Passa-Cinco, sistema do alto rio Paraná, foi realizada com o objetivo de investigar os hábitos alimentares desta espécie, verificar possíveis variações espaciais na dieta e investigar a influência da vegetação ripária na composição da dieta. Foram analisados 243 estômagos através dos métodos de frequência relativa de ocorrência e volumétrico, e a dieta caracterizada através do índice alimentar $\left(\mathrm{AI}_{\mathrm{i}}\right)$. A espécie apresentou hábito alimentar insetívoro, com o predomínio de insetos terrestres e aquáticos na dieta, variando de acordo com o local. Na maioria dos riachos, os recursos mais consumidos foram os de origem alóctone. A participação de insetos aquáticos e vegetais terrestres foram elevadas na maioria dos riachos, enquanto que insetos e invertebrados terrestres apresentaram maior contribuição nos riachos com maior presença de floresta ripária. Os dois riachos drenando áreas de pastagens foram os únicos locais onde $A$. paranae consumiu algas e fragmentos de macrófitas. Esses resultados são corroborados pela análise de similaridade (ANOSIM), onde o descritor ambiental "porcentagem de floresta ripária" foi aquele de maior influencia na dieta de $A$. paranae. O estudo mostra que a porcentagem de floresta na zona ripária define a composição da dieta da espécie naquele trecho de riacho, mas que $A$. paranae também é capaz de obter recursos alimentares em uma variedade de ambientes degradados.
\end{abstract}

PALAVRAS-CHAVE. Ecologia alimentar, Characiformes, peixes insetívoros, fatores ambientais.

Stream ecosystems are spatially heterogeneous, regarding both the diversity of habitats, water flow, depth, temperature and substrate (FrISSELL \& LONZARICH, 1996). These factors are closely related to the vegetative composition of the interface between terrestrial and aquatic ecosystems, the riparian zone. In headwater streams, riparian forests play a major role in the regulation of energy flow and nutrient cycling (VANNOTE et al., 1980). The presence of riparian forest influences primary production (which is regulated by shading and the input of plant debris) and trophic groups of macroinvertebrates and fish (VAnNote et al., 1980; Gregory et al., 1991; Johnson \& Covich, 1997). Land cover in riparian zone streams is strongly related to the physical and chemical characteristics of water (OMETTO et al., 2000; SUTHERLAND et al., 2002; Meador \& Goldstein, 2003; Diana et al., 2006) and the characteristics of the substrate (WATERS, 1995; Sponseller et al., 2001; Allan, 2004; Ferreira \& CASATTI, 2006). The absence of riparian forest may result in a greater transference of sediment to water bodies, increasing turbidity with subsequent habitat loss via sedimentation (Ferreira \& CASATTI, 2006; Silva et al., 2007; KASANGAKI et al., 2008).
Changes in land cover of watersheds and riparian areas primarily alter the structure of aquatic macroinvertebrates assemblages, such as species richness and diversity (SPONSELler et al., 2001; CORBI $\&$ Trivinho-Strixino, 2006) and the input of terrestrial invertebrates (HENRY et al., 1994). Anthropogenic modifications of aquatic ecosystems may influence the survival of many fish species by directly reducing resources availability or indirectly affecting other links in the food chain. Riparian land cover changes also trigger changes in stream fish fauna (Rowe et al., 1999; Growns et al., 2003). Allochthonous food sources for stream fish are being destroyed even before there is a better understanding of the interaction between the environment and the ichthyofauna (Esteves \& ARANHA, 1999).

The Paraná River basin drains $1.5 \times 10^{6} \mathrm{~km}^{2}$, including highly urbanized areas, industrial and agricultural complexes, and represents the most intensively exploited region in Brazil (Agostinho \& Julio Junior, 1999). The Passa-Cinco River basin, a sub-basin of the Corumbataí River (a river from the Upper Paraná River system), has a long history of 
anthropogenic occupation and an agricultural matrix dominated by pasture and sugar cane. Even though this geographic region has the highest percentage of forest remnants (15\%) among Corumbataí sub-basins (VALENTE \& Vettorazzi, 2002), its riparian forests were also affected by anthropogenic occupation.

Astyanax paranae Eigenmann, 1914 is the species with the highest occurrence in a study of 60 streams of the Corumbataí River Basin (SP), among those with the greatest number of individuals and total biomass (Pedro Gerhard, unpublished data). Astyanax paranae is considered one of the most common species in the upper Paraná River, and usually inhabits rivers and streams, establishing numerous subpopulations isolated from each other in upland streams (GARUTTI \& BRITSKi, 2000; ShibatTA et al., 2007). This species is also present in lentic environments, such as reservoirs in catchment areas of Piquiri and Tibagi rivers, state of Paraná (PR) (Luiz et al., 2005; AвELHa et al., 2006). The type locality of $A$. paranae species is a tributary of the Paranapanema River in the upper Tibagi River (GARUTTI $\&$ BRITSKI, 2000). The species was usually classified as A. scabripinnis paranae, part of a large species group termed by Moreira-Filho \& Bertollo (1991) as the "scabripinnis complex". Recently, all subspecies were elevated to the species level (Lima et al., 2003). Although a detailed study is still needed, "Astyanax paranae" is currently used to designate populations of the A. scabripinnis complex of the upper Paraná River system (Ribeiro et al., 2006), an usage that is herein accepted.

Considering the wide distribution and abundance of A. paranae in the upper Paraná River system, and the different degrees of human disturbance of these places, the objectives of this study were to investigate the diet composition of $A$. paranae from stream reaches bordered by distinct riparian vegetation and its possible relations with environmental descriptors (structural characteristics of the channels and water).

\section{MATERIAL AND METHODS}

The Passa-Cinco River basin $(52,657.60$ ha) is located in central-eastern of state of São Paulo (Fig. 1) and is the largest sub basin of the Corumbataí River (Valente \& Vettorazzi, 2002), belonging to the upper Paraná River system. Land cover in this basin is dominated by pasture $(52 \%)$ and fragments of native forest (16\%) (Valente \& Vettorazzi, 2002). Nine stream reaches (Fig. 1; Tab. I) were selected from this basin.

The characterization of land use and cover in riparian zone was done within a $30 \mathrm{~m}$ buffer around a $150 \mathrm{~m}$ stream stretch. This detailed characterization was obtained by photointerpretation (JENSEN, 2000) based on georefered aerial photographs (color, year 2000, scale 1:30,000). These procedures were conducted in ArcGis

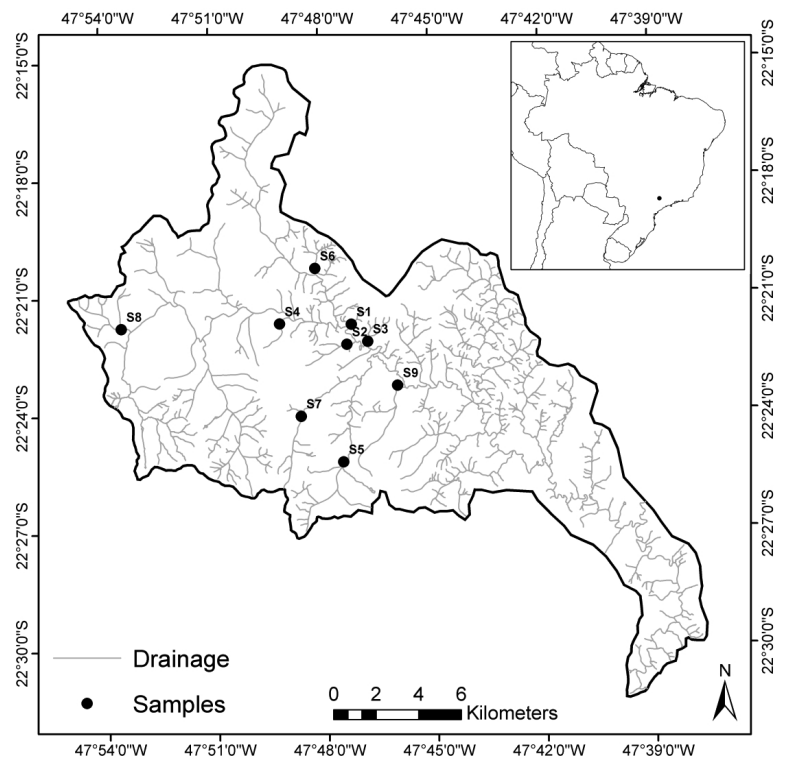

Fig. 1. Location of the nine stretches of streams studied in the Passa-Cinco River basin, state of São Paulo, located in the upper Paraná River system, southeastern Brazil.

9.2, adopting the UTM coordinate system, zone $23 \mathrm{~S}$, datum Córrego Alegre. The environmental descriptors (percentage of shaded channel area, relation between pool/riffle area, average and variance of channel depth, diversity of substrate, percentage of sand in the substrate, dissolved oxygen, turbidity and total suspended sediments) were obtained by standard methods of stream habitat characterization (see FitZPATRICK et al., 1998; Hauer \& LAMBerti, 2007), just before fish sampling (Tab. II).

Fish were collected once in each stream reach between the months of February and March 2003, using an electro-fishing apparatus. This method was applied to a sample reach of 150 meters in length in each stream, with three consecutive passes. Additional collections were made with seine nets and wire mesh sieves in places where the number of individuals captured with electrofishing was not enough for the analysis of stomach contents $(>10)$. In the field, fish were fixed in $10 \%$ formalin and later preserved in $70 \%$ alcohol. Specimens were measured (standard length) and weighed, and stomachs excised and preserved in $70 \%$ alcohol. Voucher specimens were deposited in the Coleção de Peixes do Departamento de Zoologia e Botânica do Instituto de Biociências, Letras e Ciências Exatas, UNESP, São José do Rio Preto, SP (DZSJRP008484).

Analysis of stomach contents was performed under both stereoscopic and optical microscopes. Food items were identified to the lowest possible taxonomic level. Stomach contents were analyzed according to the methods of frequency of occurrence (HysLOP, 1980) and volumetry (Hellawel \& ABEL, 1971). The Alimentary Index $\left(\mathrm{AI}_{\mathrm{i}}\right)$ was calculated to characterize the diet of the species (KaWAKami \& VAzzoler, 1980): $\mathrm{AI}_{\mathrm{i}}=\left[\left(\mathrm{F}_{\mathrm{i}} \mathrm{X}\right.\right.$ $\left.\left.\mathrm{V}_{\mathrm{i}}\right) / \Sigma\left(\mathrm{F}_{\mathrm{i}} \times \mathrm{V}_{\mathrm{i}}\right)\right] \times 100$, where $\mathrm{F}_{\mathrm{i}}$ is the relative frequency 
Tab. I. Location of stream reaches sampled in the Passa-Cinco River basin, state of São Paulo, southeastern Brazil. Coordinates, determined at downstream end of each sampled stretch, are presented in UTM projection, Zone 23S datum Córrego Alegre.

\begin{tabular}{|c|c|c|c|c|}
\hline \multirow{2}{*}{ Codes } & \multirow{2}{*}{ Streams } & \multirow{2}{*}{ Order } & \multicolumn{2}{|c|}{ Coordinates } \\
\hline & & & $\mathrm{X}$ & $\mathrm{y}$ \\
\hline $\mathrm{S} 1$ & $\begin{array}{l}\text { Tributary of the } \\
\text { Passa-Cinco River }\end{array}$ & 3 & 212.855 & 7.524 .264 \\
\hline $\mathrm{S} 2$ & Areião & 2 & 212.772 & 7.523 .433 \\
\hline S3 & Paredão & 3 & 213.780 & 7.523 .554 \\
\hline S4 & $\begin{array}{l}\text { Tributary of the } \\
\text { Passa-Cinco River }\end{array}$ & 1 & 209.656 & 7.524 .386 \\
\hline S5 & Lapa & 3 & 212.570 & 7.517 .764 \\
\hline S6 & $\begin{array}{l}\text { Tributary of the } \\
\text { Pirapitinga Stream }\end{array}$ & 3 & 211.263 & 7.526 .995 \\
\hline S7 & Cantagalo & 3 & 210.591 & 7.520 .027 \\
\hline S8 & Anzol & 3 & 202.183 & 7.524 .105 \\
\hline S9 & Rochedo & 2 & 215.151 & 7.521 .401 \\
\hline
\end{tabular}

of occurrence of item $i$ and $V_{i}$ is the relative volume of item i. The overall diet was also explored through the graphical analysis proposed by Costello (1990). This method consists of a two-dimensional plot, presenting the percentage contribution of the occurrence (x axis) and percentage of volume (y axis) of the food groups.

Food items were grouped into broad food categories: terrestrial insects (Ephemeroptera, Odonata, Blattodea, Orthoptera, Hemiptera, Coleoptera, Diptera, Trichoptera, Lepidoptera, Hymenoptera, Formicidae, Thysanoptera and insect fragments), terrestrial invertebrates (Oligochaeta, Scorpionida, Araneae and Collembola), terrestrial plants (leaf fragments and seeds - dicotyledons and monocotyledons), aquatic insects (Ephemeroptera, Odonata, Plecoptera, Hemiptera, Megaloptera, Coleoptera, Diptera larvae and pupae, Chironomidae, Simuliidae, Trichoptera, Lepidoptera and aquatic insect fragments), aquatic plants (fragments of macrophytes), algae (filamentous algae), detritus and sediments (detritus $=$ particulate organic matter in different stages of decomposition) and others - items with low percentages (Tecameba, Nematoda, Isopoda, Amphipoda and scales). The items were also grouped according to their origin: autochthonous, allochthonous and indeterminate (origin not identified).

A similarity analysis of the diets between sampled sections was performed using a matrix with the Alimentary Index values of each food category (terrestrial insects, terrestrial invertebrates, terrestrial plants, aquatic insects, algae, and others) per sampling site. Using the statistical software PRIMER 6.0 (CLARKE \& Gorley, 2006), this matrix was transformed to square root to calculate the Bray-Curtis similarity coefficient and subsequent non-metric multidimensional scaling analyses (NMDS). In this technique, objects or species are ordered according to the similarity they present. The robustness of the analysis is represented by values of stress, where the closer to zero, the more reliable is the obtained graphical representation (CLARKE \& GoRLEy, 2006). In graphic representations of NMDS, the contribution of food items was subsequently plotted as bubbles of different sizes.

To assess whether differences in the diets between streams could be explained by environmental factors, a matrix of diet $\left(\mathrm{AI}_{\mathrm{i}}\right)$ for the sampling sites was used, and environmental factors (percentage of forest within the riparian zone on the sampled stretch, percentage of sand substrate, total suspended sediments, substrate diversity and pool/riffle relationship per area) were categorized and analyzed with a Similarity Analysis (ANOSIM), also with the aid of the software PRIMER 6, where $R$ values near zero indicate no differences between the analyzed sample sets (CLARKE \& WARWICK, 2001).

\section{RESULTS}

Stomach contents of 243 individuals of $A$. paranae sampled in nine streams were analyzed. Considering all the streams, the diet of $A$. paranae was characterized by a high consumption of terrestrial (mainly Formicidae) and aquatic insects (mainly immature stages of

Tab. II. Environmental descriptors of the studied streams in the Passa-Cinco River basin, state of São Paulo, southeastern Brazil, between February and March 2003. RF, percentage of riparian forest in the stretch sampling (\%); PA, percentage of pasture in the stretch sampling (\%); SH, shading channel per unit (\%); DE, average depth (cm); SA, percentage of sand in the substrate (\%); OD, dissolved oxygen (mg.. $\left.{ }^{-1}\right)$; TU, turbidity (FTU); SS, total suspended sediments (mg. $\left.1^{-1}\right)$; VD, variance of depth (cm); DS, Simpson diversity of the substrate; PR, relative pool/riffle $\left(\mathrm{m}^{2} \cdot \mathrm{m}^{-2}\right)$.

\begin{tabular}{rrrrrrrrrrrr}
\hline & RF & PA & SH & DE & SA & OD & TU & SS & VD & DS & PR \\
\hline S1 & 100.0 & 0.0 & 61.60 & 7.16 & 37.7 & 8.07 & 4.0 & 16.0 & 28.78 & 0.72 & 0.18 \\
S2 & 100.0 & 0.0 & 55.53 & 3.90 & 88.3 & 7.38 & 25.0 & 56.0 & 8.03 & 0.27 & 0.00 \\
S3 & 96.6 & 3.4 & 58.20 & 11.94 & 41.9 & 7.82 & 23.0 & 30.7 & 100.04 & 0.68 & 0.07 \\
S4 & 82.8 & 17.2 & 60.87 & 6.29 & 35.6 & 8.03 & 42.0 & 20.7 & 27.70 & 0.70 & 0.17 \\
S5 & 51.7 & 48.3 & 20.20 & 23.07 & 12.4 & 7.87 & 8.0 & 9.7 & 337.11 & 0.60 & 0.15 \\
S6 & 43.9 & 56.1 & 26.20 & 5.71 & 90.9 & 7.06 & 31.0 & 53.0 & 10.12 & 0.15 & 0.09 \\
S7 & 8.1 & 91.9 & 0.00 & 9.41 & 6.3 & 7.80 & 21.0 & 27.7 & 68.15 & 0.72 & 0.04 \\
S8 & 0.0 & 100.0 & 0.53 & 11.40 & 4.4 & 7.70 & 53.0 & 31.3 & 116.93 & 0.71 & 0.08 \\
S9 & 0.0 & 100.0 & 0.00 & 42.14 & 52.5 & 7.19 & 15.0 & 16.3 & 581.04 & 0.65 & 0.39 \\
\hline
\end{tabular}


Trichoptera and Ephemeroptera) (Fig. 2). Regarding the origin of food resources, the highest percentage was of allochthonous resources $(69.1 \%)$, followed by autochthonous (30.9\%) and undetermined ones $(0.05 \%)$.

Comparing the diet among the sampled streams, terrestrial and aquatic insects remained the main resources consumed by the species at all sampling sites, but the relative amount of those two food sources varied between streams (Tab. III). In the S2, S3 and S6 streams, there was a predominance of terrestrial insects $\left(\mathrm{AI}_{\mathrm{i}}>\right.$ $80 \%$ ). In the S1, S4 and S5 streams, there was a greater consumption of aquatic insects, but also an expressive ingestion of terrestrial insects, with the exception of S8 stream, where the opposite occurred. Aquatic insects only dominated the diet in stream S7, while in the stream S9, terrestrial and aquatic plants predominated.

With the exception of S5, S7 and S9 streams, there was a predominance of allochthonous resources $\left(\mathrm{AI}_{\mathrm{i}}>65 \%\right)$. In streams $\mathrm{S} 7$ and $\mathrm{S} 9$, there was a higher proportion of autochthonous resources $\left(\mathrm{AI}_{\mathrm{i}}>65 \%\right)$; proportional intake of both resources was recorded only for stream S5 (Fig. 3).

The ordering produced by NMDS showed the participation of terrestrial invertebrates and plants, aquatic insects, algae and aquatic plants for each stream stretch and the similarity of diet of the species between the streams (Fig. 4). The grouping of streams according to diet only highlighted stream S9, where there was a low contributions of terrestrial invertebrates and insects and is the only place where fragments of aquatic plants were detected. This analysis was considered robust due to its low stress (0.07), allowing reliability in interpreting these results. According to the analysis of similarity (ANOSIM), the descriptor that most influenced the diet of $A$. paranae was the percentage of riparian forest in sampled stretches $(R=0.47 ; \mathrm{ns}=1.4 \%)$.

There was a greater contribution of terrestrial insects and invertebrates in streams with the highest percentage of riparian forest (Figs 4, 5). Otherwise, aquatic insects and terrestrial plants showed a strong presence in all streams (Figs 6,7). The diet of A. paranae differed mainly in streams S8 and S9, which are both in pasture areas, being the only places where there was consumption of algae and aquatic plants (Figs 8, 9).

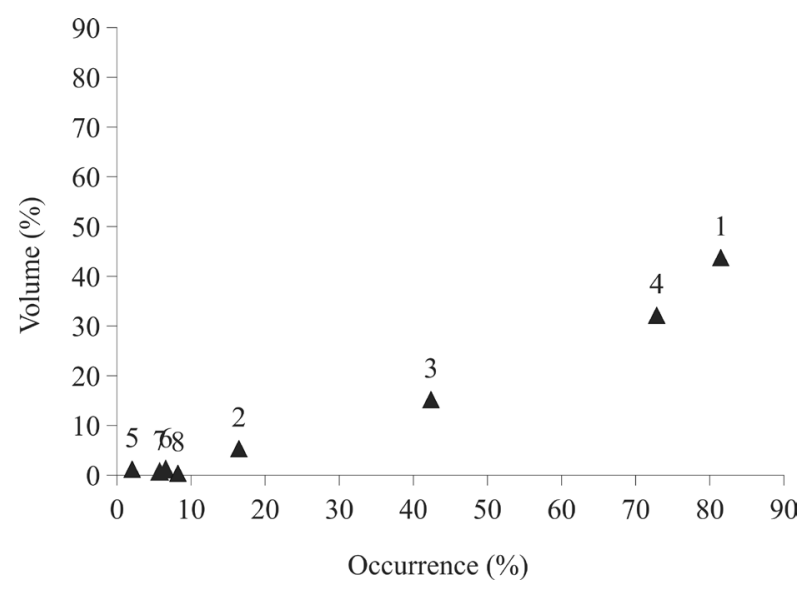

Fig. 2. Frequency of occurrence and volume of food resources utilized by Astyanax paranae Eigenmann, 1914 in streams in the Passa-Cinco River basin, state of São Paulo, southeastern Brazil, between February and March 2003 (1, terrestrial insects; 2, terrestrial invertebrates; 3, terrestrial plants; 4, aquatic insects; 5 , aquatic plants; 6 , algae; 7, detritus and sediments; 8 , others).

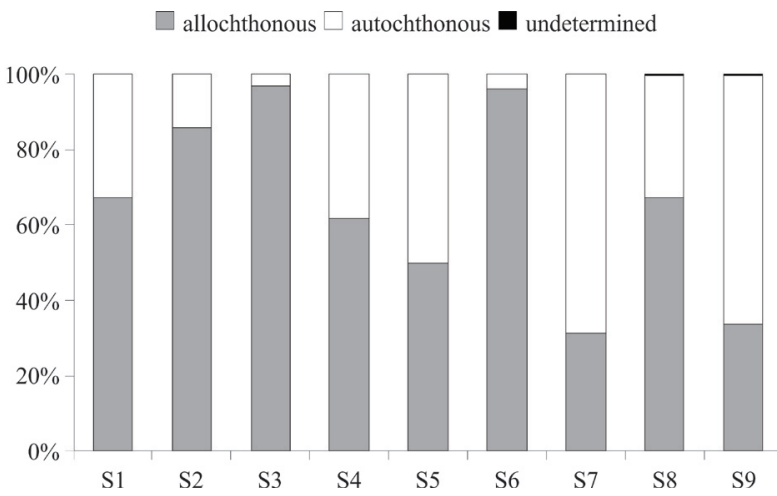

Fig. 3. Sources of food resources (AI) consumed by Astyanax paranae Eigenmann, 1914 sampled in nine streams of the Passa-Cinco River basin, state of São Paulo, southeastern Brazil, between February and March 2003.

Tab. III. Number of specimens examined (n), mean and standard deviation of standard length of the specimens ( \pm SD) and categories of food consumed (AI) by Astyanax paranae Eigenmann, 1914 sampled in nine streams of Passa-Cinco River basin, stăte of São Paulo, southeastern Brazil, between February and March 2003. Others = items with low percentages (Tecameba, Nematoda, Isopoda, Amphipoda and scales).

\begin{tabular}{|c|c|c|c|c|c|c|c|c|c|}
\hline Stream & S1 & $\mathrm{S} 2$ & S3 & S4 & S5 & S6 & S7 & S8 & S9 \\
\hline $\mathrm{n}$ & 22 & 30 & 30 & 29 & 28 & 30 & 30 & 30 & 14 \\
\hline $\mathrm{S}_{\mathrm{L}} \pm \mathrm{SD}$ & $4.41 \pm 0.82$ & $3.44 \pm 0.92$ & $4.16 \pm 1.06$ & $2.93 \pm 0.82$ & $4.09 \pm 0.91$ & $3.69 \pm 1.03$ & $4.14 \pm 0.83$ & $3.48 \pm 1.10$ & $3.16 \pm 0.69$ \\
\hline Terrestrial insects & 30.1 & 82.4 & 93.1 & 34.1 & 30.7 & 85.6 & 9.4 & 65.3 & 18.4 \\
\hline Terrestrial invertebrates & 4.2 & 0.4 & $<0.1$ & 11.2 & 0.3 & $<0.1$ & $<0.1$ & 0.2 & $<0.1$ \\
\hline Terrestrial plants & 22.1 & 3.4 & 3.6 & 11.3 & 8.3 & 9.6 & 14.4 & 5.0 & 19.4 \\
\hline Aquatic insects & 43.4 & 13.7 & 3.1 & 43.2 & 60.7 & 4.8 & 76.2 & 18.7 & 42.4 \\
\hline Aquatic plants & & & & & & & & & 19.2 \\
\hline Algae & & & & & & & & 10.1 & 0.1 \\
\hline Detritus and sediment & 0.1 & $<0.1$ & 0.2 & & $<0.1$ & & $<0.1$ & 0.5 & 0.5 \\
\hline Others & $<0.1$ & $<0.1$ & $<0.1$ & 0.3 & & & $<0.1$ & 0.2 & \\
\hline
\end{tabular}




\section{DISCUSSION}

Astyanax paranae showed an insectivorous feeding habit dominated by terrestrial insects, but aquatic insects were also important in the species' diet, and other food items were consumed in smaller proportions, which demonstrate that the species has flexibility in the search for food resources. The feeding habits reported in the literature for this species in the upper Paraná River system were insectivorous and omnivorous, both in streams and rivers habitats (UIEDA et al., 1987; CASTRO \& Casatti, 1997; Uieda et al., 1997; Roque et al., 2003; Oliveira \& Bennemann, 2005; Ferreira, 2007; Esteves et al., 2008; FerreIra et al., 2012), and detritivore in a reservoir (ABELHA et al., 2006).

When streams are analyzed separately, terrestrial and aquatic insects continued to be the main food source consumed. These resources are very important in the diet of stream fish, especially when dealing with nektonic characids, as reported by CASATTI (2002), CENEVIVABastos \& CAsatti (2007), Abilhoa et al. (2008), Borba et al. (2008), CENEVIVA-BAstos et al. (2010) and FERREIRA et al. (2012). In a stream within the Araucaria forest zone (upper Iguaçu River), insects were the main resources consumed by all fish, constituting the most important food source of that place (ABILHoA et al., 2008). The most important item in the diet of $A$. paranae in almost every sampling site is Formicidae, as reported by UIEDA et al. (1987), CAStro \& CAsatti (1997) and Roque et al. (2003); CASATti (2002) and Borba et al. (2008). The high consume of allochthonous items detected in this study emphasizes the importance of those items that fall and/or are dragged into the water for the ichthyofauna. Morphological features of nektonic characins, such as a compressed body, lateral eyes and upper lateral pectoral fins, make them good continuous swimmers, sightdependent fish, dwelling in mid-water (CASATTI et al., 2001; Ferreira, 2007), i.e., "drift feeders". Astyanax species were reported moving back and forth between the margins and the central portion of stream channels, more frequently between the surface and mid-water, with little time spent foraging on the bottom (ABILHOA et al., 2008).

The species herein studied also consumed aquatic insects in varying proportions, obtained either by the behavior of selective picking insects at the substrate or by the collection of drifting organisms. Although most streams and rivers invertebrates are benthic, drift is a common phenomena, usually occurring at twilight or during the night (SMOCK, 2007); drifting can also occur during the day, both as a result of natural (heavy rains or active dispersal) or anthropic (trampling by cattle in the water bodies) events. These anthropic events are common in the sampled areas, so that it may enhances the consumption of these resources by species that show opportunistic feeding behavior such as $A$. paranae. Along with aquatic insects, terrestrial insects fallen from the riparian vegetation are also part of the set of the adrift individuals transported by the current (RoQuE et al., 2003).

This study detected a significant high consumption of allochthonous food sources under the influence of the percentage of forest vegetation in riparian zones Allochthonous resources are considered the base of the food chain in streams, even when organisms make use of autochthonous resources, because the primary source of allochthonous origin uses nutrients from the riparian vegetation (GREGORY et al., 1991; BRETSCHKO \& Waidbacher, 2001; Sabino \& Deus e Silva, 2004). In streams of the Corumbataí River basin, upper Paraná River system, allochthonous resources were the main food items consumed by $A$. paranae in streams whose riparian zone presented forest as a dominant cover, whereas in streams where pasture predominated in the riparian zone, autochthonous resources prevailed in the diet of the species (FERreIrA et al., 2012). The three streams herein studied bearing pastures in their riparian corridors, it was recorded that $A$. paranae not only had higher proportions of aquatic insects in the diet (streams S7 and S9), but also consumed filamentous algae (S8) and fragments of macrophytes (S9). This demonstrates the species fitness that, taking advantage of its morphology and behavior, is able to gather feeding resources in altered environments, eliciting food items at different stream habitat units (pools, riffles etc.) and water compartiments (margins, streambed, midwater etc.). Not only the absence of a riparian forest, but also the fragmentation of these biotopes, can alter both stream channel structure and biota (FERREIRA et al., 2012). The absence of riparian forest seems to favor the species that possess better ability to utilize varying food items (BoJsen, 2005). Astyanax paranae was recorded in streams with contrasting conservation levels, from barely to highly impacted reaches, proving to be an opportunistic species that can also present trophic adaptability. However, abundance and biomass of this species in streams of the Corumbataí River basin were lower in streams with grassland coverage in comparison to forested streams (Anderson Ferreira, unpublished data). The absence of riparian forest influences not only the structure (abundance, richness and diversity) of fish assemblages in streams, but may also lead to changes in trophic structure of fish fauna (BOJSEN \& BARRIGA, 2002; Lorion \& KenNEDy, 2009; FerReIRA et al., 2012).

Like many streams in the Passa-Cinco River basin, S2 and S6 streams are in an advanced process of sedimentation. Riparian ecosystems are easily disrupted after deforestation, which nearly always triggers soil erosion and the formation of gullies. This leads to the sedimentation of water bodies which, in turn, results in riparian forest death due to the process of valley aggradation (JACOMINE, 2001). The reduction of forest cover, particularly in riparian areas, is closely linked to increased sediment transport to aquatic environments 


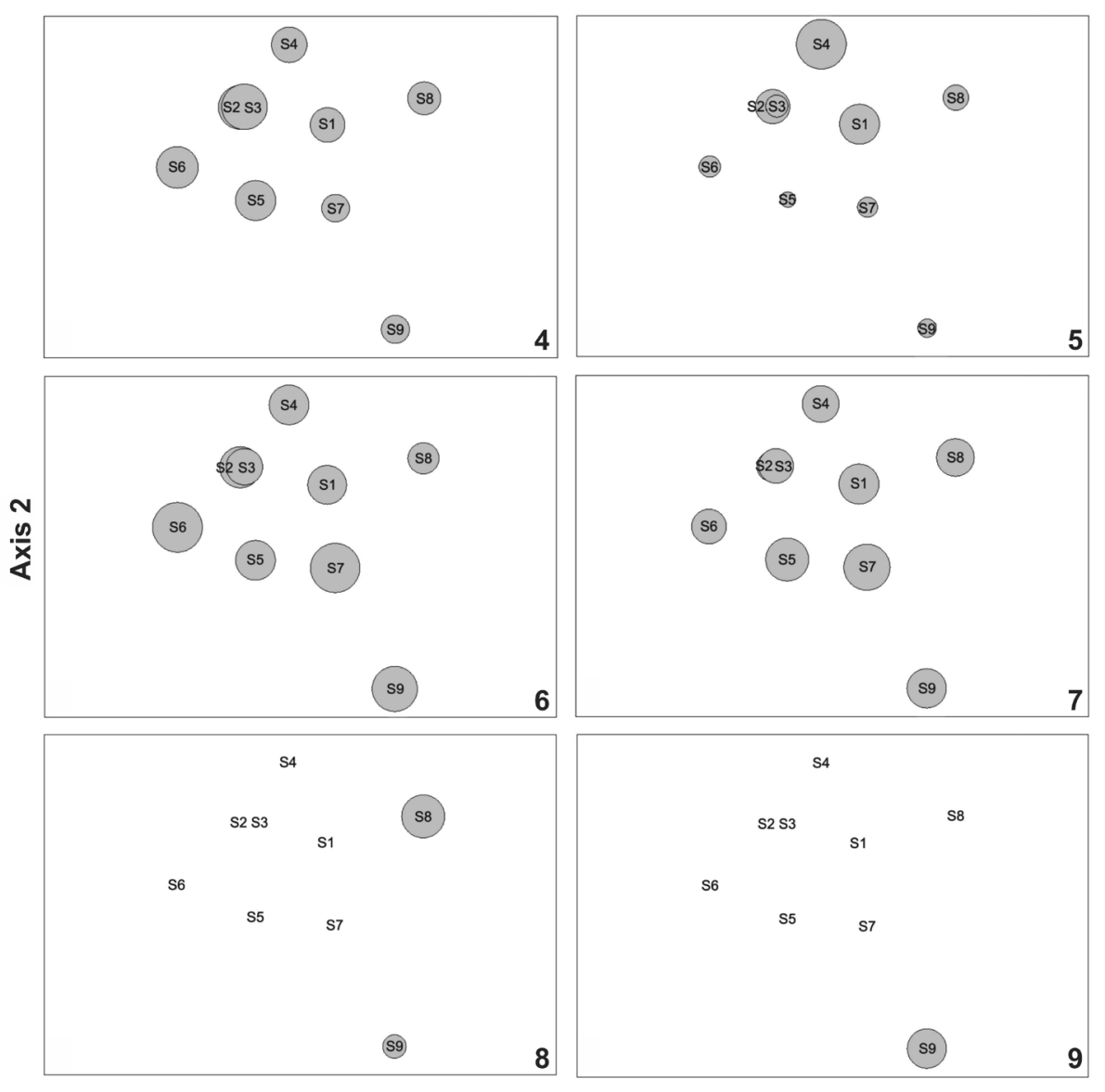

Axis 1

Figs 4-9. Graphic representation of the non-metric multidimensional scaling analysis (NMDS) applied to the diet of Astyanax paranae Eigenmann, 1914 sampled in nine streams of Passa-Cinco River basin, state of São Paulo, southeastern Brazil, between February and March 2003. Contribution of food items represented as the size of the circle: 4 , terrestrial insects; 5 , terrestrial invertebrates; 6 , terrestrial plant; 7 , aquatic insects; 8, algae; 9, aquatic plant. Stress: 0.07.

and alterations to the physical properties of the water, such as increased turbidity, causing sedimentation and habitat loss (Allan et al., 1997; SPONSELLER et al., 2001; Sutherland et al., 2002; Ferreira \& CAsatti, 2006; Silva et al., 2007; CASATTI et al., 2009). As a matter of fact, CASATTi et al. (2009) reported a simplification of habitats and fauna in streams of northwest of state of São Paulo with predominance of pasture in their basins. Particularly at S2, its streambed was completely sand filled and the riparian vegetation was failing. Despite the presence of a conspicuous forest cover in the riparian zone of stream S2, and the presence of some forest cover in S6 reach, the upland areas of these streams are degraded, both at upstream reaches along the valley floor and at the hillslopes. This poor catchment conservation status is responsible by the high sedimentation observed at the sampled sites, verified by its low mean stream depths and low substrate diversity. This singularities are markedly affecting both the fish fauna and possible food sources, given the destruction of habitats and micro-habitats units. In these streams, the consumption of allochthonous resources was a common finding. Most individuals caught in these streams occurred in small $\left(<1 \mathrm{~m}^{2}\right)$ pools along the margins, created either by bank collapse, which is fragile due to the lack of woody vegetation, or by direct cattle tramping that creat small "pothole" pools. At these minute habitat subunits, individuals could explore not only food items fallen from the surrounding riparian vegetation, but also resources adhered to suspended roots of aquatic or terrestrial (mostly grass) plants. Thus, although a shift on the species diet was detected, A. paranae is still able to cope with a large amount of stream channel degradation due to riparian and upland areas deforastation and heavy cattle grazing coupled to poor soil conservation practices.

Astyanax paranae is a common species, recorded from highly anthropized to nearly pristine environments throughout the Passa Cinco River basin. This indicates that the species is not only occupying marginally profitable environments, such as streams bordered by grassland riparian areas, but also more plentiful reaches, bordered by riparian forests. It is at those sites that terrestrial insects are most important items in the diet of A. paranae. This observation reinforces the importance of the forest presence in the riparian corridors of upland streams, providing not only allocthonous resources needed to assist authocthonous food chains, but also to 
maintain the structural integrity of the stream channels and water quality. Equally important is to adopt good practices of soil conservation to avoid the loss of sediments from the slopes of the watershed to the valley floor. The absence and fragmentation of riparian forests forced A. paranae to use alternative food sources, especially the autochthonous items. This dietary change may drive local fish fauna to intra and inter-specific competition (BARRETO \& ARANHA, 2006), which, at its maximum negative extent, might lead to the species local extinction.

Acknowledgements. Authors are indebted to Prof. Dr. Luciano M. Verdade for providing the required infrastructure to carry out this work; Gabriel L. Brejão, Henrique Sawakuchi, Maurício T. Filho, Ricardo A. Brassaloti and Bruno H. C. Cavichiolli who helped with the field and lab work; Rosa M. Dias for their help in laboratory and discussion of data; Felipe R. de Paula for land cover data and preparing the map of the study area; Dra. Cristiane P. Ferreira, who helped with data analysis, reading and suggestions to the manuscript. CAPES and FAPESP (process number 00/14284-0) provided required financial support for the project. Three anonymous referees provided valuable insights to the final version of the manuscript.

\section{REFERENCES}

Abelha, M. C. F.; Goulart E.; Kashiwaqui, E. A. L. \& Silva, M. R. 2006. Astyanax paranae Eigenmann, 1914 (Characiformes: Characidae) in the Alagados Reservoir, Paraná, Brazil: diet composition and variation. Neotropical Ichthyology 4(3):349356.

AbilhoA, V.; Duboc, L. F. \& Azevedo-Filho, D. P. 2008. A comunidade de peixes de um riacho de Floresta com Araucária, alto rio Iguaçu, sul do Brasil. Revista Brasileira de Zoologia 25(2):238-246.

Agostinho, A. A. \& Julio Junior, H. F. 1999. Peixes da bacia do alto rio Paraná. In: Lowe-McConnell, R. H. ed. Estudos ecológicos de comunidades de peixes tropicais. São Paulo, EDUSP. p.374400.

Allan, J. D. 2004. Landscapes and riverscapes: the influence of land use on stream ecosystems. Annual Review of Ecology and Systematics 35:257-284.

Allan, J. D.; Erickson, D. L. \& Fay, J. 1997. The influence of catchment land use on stream integrity across multiple spatial scales. Freshwater Biology 37:149-161.

Barreto, A. P. \& Aranha, J. M. R. 2006. Alimentação de quatro espécies de Characiformes de um riacho de floresta Atlântica, Guaraqueçaba, Paraná, Brasil. Revista Brasileira de Zoologia 23(3):779-788.

BoJsen, B. H. 2005. Diet and condition of three fish species (Characidae) of the Andean foothills in relation to deforestation. Environmental Biology of Fishes 73:61-73.

Bojsen, B. H. \& BARRIGa, R. 2002. Effects of deforestation on fish community structure in Ecuadorian Amazon streams. Freshwater Biology 47:2246-2260.

Borba, C. S.; Fugi, R.; Agostinho, A. A. \& Novakowski, G. C. 2008. Dieta de Astyanax asuncionensis (Characiformes, Characidae), em riachos da bacia do rio Cuiabá, Estado do Mato Grosso. Acta Scientiarum, Biological Sciences 30(1):39-45.

BretschKo, G. \& WAidBACHeR, H. 2001. Riparian ecotones, invertebrates and fish: life cycle timing and trophic base. Ecohydrology \& Hydrobiology 1(1/2):57-64.

CasatTi, L. 2002. Alimentação dos peixes em um riacho do Parque Estadual Morro do Diabo, bacia do alto rio Paraná, sudeste do Brasil. Biota Neotropica 2(2):1-14.

Casatti, L.; Ferreira, C. P. \& Carvalho, F. R. 2009. Grass-dominated stream sites exhibit low fish species diversity and dominance by guppies: an assessment of two tropical pasture river basins. Hydrobiologia 632:273-283.

Casatti, L.; Langeani, F. \& Castro, R. M. C. 2001. Peixes de riacho do Parque Estadual Morro do Diabo, bacia do alto rio Paraná, SP. Biota Neotropica 1(1):1-15.
Castro, R. M. C. \& CAsatti, L. 1997. The fish fauna small forest stream of the upper Paraná river basin, southeastern Brazil. Ichtyological Exploration Freshwaters 7(4):337-352.

Ceneviva-Bastos, M. \& Casatti, L. 2007. Oportunismo alimentar de Knodus moenkhausii (Teleostei, Characidae): uma espécie abundante em riachos do noroeste do Estado de São Paulo, Brasil. Iheringia, Série Zoologia 97(1):7-15.

Ceneviva-Bastos, M.; Casatti, L. \& Rossa-Feres, D. D. 2010. Meso and microhabitat analysis and feeding habits of small nektonic characins (Teleostei: Characiformes) in Neotropical streams. Zoologia 27(2):191-200.

Clarke, K. R. \& Gorley, R. N. 2006. Primer v6: user manual/ tutorial. Plymouth, Plymouth Marine Laboratory. 190p.

Clatrke, K. R. \& Warwick, R. M. 2001. Change in marine communities: an approach to statistical analysis and interpretation. Plymouth, Primer-E. 172p.

Corbi, J. J. \& Trivinho-Strixino, S. 2006. Influence of taxonomic resolution of stream macroinvertebrate communities on the evaluation of different land uses. Acta Limnologica Brasiliensia 18(4):469-475.

Costello, M. J. 1990. Predador feeding strategy and prey importance: a new graphical analysis. Journal of Fish Biology 36:261-263.

Diana, M.; Allan, J. D. \& Infante, D. 2006. The influence of physical habitat and land use on stream fish assemblages in southeastern Michigan. American Fisheries Society Symposium 48:359-374.

Esteves, K. E. \& Aranha, J. M. R. 1999. Ecologia trófica de peixes de riachos. In: Caramashi, E. P.; Mazzoni, R. \& Peres-Neto, P. R. eds. Ecologia de peixes de riachos. (Série Oecologia Brasiliensis, volume VI). Rio de Janeiro, PPGE-UFRJ. p.157-182.

Esteves, K. E.; Lobo, A. V. P. \& Faria, M. D. R. 2008. Trophic structure of a fish community along environmental gradients of a subtropical river (Paraitinga River, Upper Tietê River Basin, Brazil). Hydrobiologia 598:373-387.

Ferreira, A.; Paula, F. R. P.; Ferraz, S. F. B.; Gerhard, P.; Kashiwaqui, E. A. L.; Cyrino, J. E. P.\& Martinelli, L. A. 2012. Riparian coverage affects diets of characids in neotropical streams. Ecology Freshwater Fish 21:12-22

Ferreira, C. P. \& CASATti, L. 2006. Influência da estrutura do hábitat sobre a ictiofauna de um riacho em uma micro-bacia de pastagem, São Paulo, Brasil. Revista Brasileira de Zoologia 23(3):642-651.

Ferreira, K. M. 2007. Biology and ecomorphology of stream fishes from the rio Mogi-Guaçu basin, Southeastern Brazil. Neotropical Ichthyology 5(3):311-326.

Fitzpatrick, F. A.; Waite, I. R., D'Arconte, P. J.; Meador, M. R.; Maupin, M. A. \& GURTZ, M. E. 1998. Revised methods for characterization of stream habitat in the national-qualityassessment program. Raleigh, U.S. Geological Survey. 77p.

Frissel, C. A. \& LonZarich, D. G. 1996. Habitat use and competition among stream fishes. In: Hauer, F. R. \& Lamberti, G. A. eds. Methods in Stream Ecology. San Diego, Academic Press. p.493510 .

Garutti, V. \& Britski, H. A. 2000. Descrição de uma espécie nova de Astyanax (Teleostei: Characidae) da bacia do alto rio Paraná e considerações sobre as demais espécies do gênero na bacia. Comunicações do Museu de Ciências e Tecnologia da PUCRS, Série Zoologia 13:65-88.

Gregory, S. V.; Swanson, F. J.; McKee, W. A. \& Cummins, K. W. 1991. An ecosystem perspective of riparian zones: focus on links between land and water. Bioscience 41(8):540-551.

Growns, I.; Gehrke, P. C.; Astles, K. L. \& Pollard, D. A. 2003. A comparison of fish assemblages associated with different riparian vegetation types in the Hawkesbury-Nepean River system. Fisheries Mangement and Ecology 10:209-220.

Hauer, F. R. \& Lamberti, G. A. 2007. Methods in Stream Ecology. San Diego, Academic Press. 877p.

Hellawell, J. \& Abel, R. 1971. A rapid volumetric method for the analysis of the food of fishes. Journal of Fish Biology 3:29-37.

Henry, R.; Uieda, V. S.; Afonso, A. A. O. \& KikUChi, R. M. 1994. Input of allochthonous matter and structure of fauna in a Brazilian headstream. Verhandlungen der Internationalen Vereinigung fur Theoretische und Angewandte Limnologie 25:1866-1870.

HysLop, E. J. 1980. Stomach contents analysis - a review of methods and their applications. Journal of Fish Biology 17:411-429.

JAComine, P. K. T. 2001. Solos sob matas ciliares. In: Rodrigues, R. B. \& Leitão-Filho, H. F. eds. Matas Ciliares: conservação e recuperação. São Paulo, EDUSP. p.27-31. 
Jensen, J. R. 2000. Remote sensing of the environment: an earth resource perspective. Saddle River, Prentice Hall. 544p.

Johnson, S. \& Covich, A. P. 1997. Scales of observation of riparian forests and distributions of supended detritus in a prairie river. Freshwater Biology 37:163-175.

Kasangaki, A.; Chapman, L. J. \& Balirwa, J. 2008. Land use and the ecology of benthic macroinvertebrate assemblages of high-altitude rainforest streams in Uganda. Freshwater Biology 53:681-697.

Kawakami, E. \& Vazzoler, G. 1980. Método gráfico e estimativa de índice alimentar aplicado no estudo de alimentação de peixes. Boletim do Instituto Oceanográfico 29(2):205-207.

Lima, F. C. T.; Malabarba, L. R.; Buckup, P. A.; Silva, J. F. P.; Vari, R. P.; Harold, A.; Benine, R.; Oyakawa, O. T.; Pavanelli, C. S.; Menezes, N. A.; Lucena, C. A. S.; Malabarba, M. C. S. L.; Lucena, Z. M. S.; Reis, R. E.; Langeani, F.; Casatti, L.; Bertaco, V. A.; Moreira, C. \& Lucinda, P. H. F. 2003. Characidae. In: Reis, R. E.; Kullander, S. O. \& FERRARIS JR, C. J. eds. 2003. Check list of the freshwater fishes of South and Central America. Porto Alegre, Edipucrs. p.104-169.

Lorion, C. M. \& Kennedy, B. P. 2009. Riparian forest buffers mitigate the effects of deforestation on fish assemblages in tropical headwater streams. Ecological Applications 19(2):468-479.

Luiz, E. A.; Petry, A. C.; Pavanelli, C. S.; Júlio Júnior, H. F.; Latini, J. D. \& Domingues, V. M. 2005. As assembléias de peixes de reservatórios hidrelétricos do estado do Paraná e bacias limítrofes. In: Rodrigues, L.; Thomaz, S. M.; Agostinho, A. A. \& Gomes, L. C. eds. Biocenose em reservatórios: padrões espaciais e temporais. São Carlos, RIMA Editora. p.169-184.

Meador, M. R. \& Goldstein, R. M. 2003. Assessing water quality at large geographic scales: relations among land use, water physicochemistry, riparian condition, and fish community structure. Environmental Management 31(4):504-517.

Moreira-Filho, O. \& Bertollo, L. A. C. 1991. Astyanax scabripinnis (Pisces, Characidae): a species complex. Revista Brasileira de Genética 14(2):331-357.

Oliveira D. C. \& Bennemann, S. T. 2005. Ictiofauna, recursos alimentares e relações com as interferências antrópicas em um riacho urbano no sul do Brasil. Biota Neotropica 5(1):1-13.

Ometto, J. P. H. B.; Martinelli, L. A.; Ballester, M. V. R.; Gessner, A.; Krusche, A.; Victoria, R. L. \& Willians, M. 2000. Effects of land use on water chemistry and macroinvertebrates in two streams of Piracicaba river basin, southeast Brazil. Freshwater Biology 44:327-337.

Ribeiro, A. C.; Lima, F. C. T.; Riccomini, C. \& Menezes, N. A. 2006. Fishes of the Atlantic Rainforest of Boracéia: testimonies of the Quaternary fault reactivation within a Neoproterozoic tectonic province in Southeastern Brazil. Ichthyological Exploration of Freshwaters 7(2):157-164.
Roque, F. O.; Pepinelli, M.; Fragoso, E. N.; Ferreira, W. A.; Barillari, P. R.; Yoshinaga, M. Y.; Strixino, S. T.; Verani, N. F. \& Lima, M. I. S. 2003. Ecologia de macroinvertebrados, peixes e vegetação ripária de um córrego de primeira ordem em região de cerrado do Estado de São Paulo (São Carlos, SP). In: Henry, R. ed. Ecótonos nas interfaces dos ecossistemas aquáticos. São Carlos, Rima. p.313-338.

Rowe, D. K.; Chisnall, B. L.; Dean, T. L. \& Richardson, J. 1999. Effects of land use on native fish communities in east coast streams of the North Island of New Zealand. New Zealand Journal of Marine and Freshwater Research 33:141-151.

Sabino, J. \& Deus e Silva, C. P. 2004. História natural de peixes da estação ecológica Juréia-Itatins. In: Marques, O. A. V. \& Duleba, W. eds. Estação ecológica Juréia-Itatins: ambiente físico, flora e fauna. Ribeirão Preto, Holos. p.230-242.

Shibatta, O. A.; Gealh, A. M. \& Bennemann, S. T. 2007. Ictiofauna dos trechos alto e médio da bacia do rio Tibagi, Paraná, Brasil. Biota Neotropica 7(2):125-134.

Silva, A. M.; Casatil, L.; Alvares, C. A.; Leite, A. M.; Martinelli, L. A. \& Durrant, S. F. 2007. Soil loss risk and habitat quality in streams of a meso-scale river basin. Scientia Agricola 64(4):336-343.

Smock, L. A. 2007. Macroinvertebrate dispersal. In: Hauer, F. R. \& Lamberti, G. A. eds. Methods in Stream Ecology. 2ed. San Diego, Academic Press. p.465-487.

Sponseller, R. A.; Benfield, E. F. \& Valett, H. M. 2001. Relationships between land use, spatial scale and stream macroinvertebrate communities. Freshwater Biology 46:1499-1424.

Sutherland, B.; Meyer, J. L. \& Gardiner, E. P. 2002. Effects of land cover on sediment regime and fish assemblage structure in four southern Appalachian streams. Freshwater Biology 47:17911805.

Uieda, V. S.; Buzzato, P. \& Kinuchi, R. M. 1997. Partilha de recursos alimentares em peixes em um riacho de serra do sudeste do Brasil. Anais da Academia Brasileira de Ciências 69(2):243-252.

Uieda, V. S.; Uieda, W.; Carneiro, A. B. C.; Silveira, S. A.; Melo, M. L. S. \& Dornelas, R. H. 1987. Rede alimentar em duas comunidades de um riacho de água doce. Anais dos Seminários de Ciências da FIUBE 1:97-113.

Valente, R. O. A. \& Vettorazzi, C. A. 2002. Análise da estrutura da paisagem na bacia do rio Corumbataí, SP. Scientia Florestalis 62:114-129.

Vannote, R. L.; Minshall, G. W.; Cummins, K. W.; Sedell, J. R. \& Cushing, C. E.1980. The river continuum concept. Canadian Journal of Fisheries and Aquatic Sciences 37:130-137.

Waters, T. F. 1995. Sediment in streams. American Fisheries Society Monographs 7:79-118.

Recebido em 25 de julho 2011. Aceito em 27 de fevereiro de 2012. ISSN 0073-4721

Artigo disponível em: www.scielo.br/isz 